\title{
Charlie Hebdo Saldırısının Türk ve Fransız Basınındaki Sunumu
}

\author{
N. Tülay Șeker ${ }^{1}$ \\ Deniz Yağız
}

\begin{abstract}
Öz
İletişim araşıtımalarında eleştirel yaklaşım habere ait değerlendirmelerde, haber üretim sürecinin iktidar ve güç ilişkileri tarafından belirlendiğini ve haber metninin bir söylem olduğunu kabul eder. Bu görüşten hareketle oluşturulan bu çalışmada, 07 Ocak 2015 tarihinde, Fransız mizah dergisi Charlie Hebdo'ya yapılan saldıının Türk ve Fransız yazılı basında sunumu ele alınmıştır. İki ülkeye ait yazılı basından farklı siyasi görüş ve ideolojilere sahip toplam 6 gazete seçilmiş, gazetelerin olayın duyurulduğu ilk güne ait haberleri eleştirel söylem analizi yöntemiyle analiz edilmiştir. Analiz sonucunda elde edilen bulgular, aynı olay üzerine üretilen haberlerin, farklı gazetelerde, farkı içerik ve sunuş biçimleriyle yer aldığını göstermiştir. Bu farklılığın gazetelerin ideolojik duruşlarından ve seslendikleri hedef kitlenin beklentilerinden kaynaklandığı sonucuna varılmıştır.
\end{abstract}

Anahtar Kelimeler: Haber, Söylem, İdeoloji, Charlie Hebdo saldırısı.

\section{The Presentation Of The Charlie Hebdo Attack In Turkish and French Presses}

\begin{abstract}
In communication researches, while evaluating the news, the critical argument is approving that news making process is determined by power relations and that news story is a discourse. Based on that view point, this paper deals about the presentation of the news regarding the attack happened on the $7^{\text {th }}$ of January 2015 towards the French satirical magazine Charlie Hebdo in Turkish and French written press. Six newspapers having different political views and ideologies have been chosen from the written press of the two countries and the news announcing the fact the first day of the incident have been analyzed with the critical discourse analysis method. The results of the analysis show that the news produced regarding the same incident are presented differently, i.e. with different contents in different newspapers. It is concluded that this diversity is based on different ideological stances of newspapers and on expectations of the reader groups targeted.
\end{abstract}

Keywords: News, Discourse, Ideology, Charlie Hebdo attack.

1 Doç.Dr. Akdeniz Üniversitesi İletişim Fakültesi Radyo Televizyon ve Sinema Bölümü

2 Akdeniz Üniversitesi İletişim Fakültesi İletişim Ana Bilim Dalı Doktora Öğrencisi 


\section{Giriș}

$\mathrm{H}$ aber kavramının neyi ifade ettiği, haberin nasıl ortaya çıktığı, ne şekilde üretildiği, hedeflediği kitle üzerindeki etkileri, siyasal ve toplumsal sonuçları yıllardır süregelen araştırmaların odağında yer almış sorulardır. Öte yandan haberin gerçekle olan ilişkisi ve ideolojinin haber söylemindeki yeri üzerine kabul edilen görüşler, bu alanda yapılan haber üretim süreci ve haber metni analiz çalışmalarını etkilemiştir.

Habercinin nesnel duruşunu öne çıkaran liberal çoğulcu yaklaşımlar, haberin yanlılığını incelerken, eleştirel yaklaşımlar, haberi şekillendiren ekonomik-politik yapılara, ideoloji ve söylem özelliklerine, haberdeki hegemonya mücadelesine yoğunlaşmışlardır. Eleştirel yaklaşım, haberin bir söylem olduğu ve ideolojiden bağımsız değerlendirilemeyeceği kabulünden hareket etmektedir. Özellikle 1970'lerden sonra haber üzerine yapılan farklı çalışmalarda ulaşılan sonuçlarla, haberin ideolojik bir söylem olduğu görüşü desteklenmiştir. Bu görüşü savunan Kültürel Çalışmalar ekolünün en önemli temsilcilerinden Stuart Hall, eleştirel söylem analizi yöntemiyle, haberin üretim sürecini etkileyen ideolojiyi açığa çıkartarak, anlam ve tahakküm arasındaki bağlantının altını çizmiştir.

Bu çalışmada, 07 Ocak 2015 tarihinde, Fransa'nın başkenti Paris'te bulunan Charlie Hebdo mizah dergisinin ofisine yönelik gerçekleştirilen saldırının ardından Türk ve Fransız basınında yer alan haberler ele alınmıştır. Bunun için farklı siyasi görüşleri temsil eden Türk ve Fransız gazetelerinden seçilerek, gazetelerin olayı duyurdukları haberleri Van Dijk'ın söylem analizi yöntemi ile incelenmiştir. Yeni Akit, Hürriyet, BirGün, Le Monde, Le Figaro, La Croix gazetelerinden haberlerin incelendiği analizle, basında ve uluslararası arenada özellikle İslam karşıtlığı ve İslami terör açısından çokça tartışılmış olan bu terör saldırısına ilişkin, analize konu olan gazetelerin kendi ideolojik duruşlarını ve yayın politikalarını haber metinlerine nasıl yansıttıklarına bakılmıştır. Elde edilen sonuçlarla, gazetelerin ideolojik yapılarının haber üretim süreçlerine ve söylem metnine etkilerini görmek amaçlanmıştır.

\section{Haber Üretim Süreci, İdeoloji ve Söylem}

Haber üretimi sürecini ele alan nicel ve nitel çalışmalar yıllar boyu çeşitlilik göstermiş olsa da, Lippman'ın 1922 yılında yayınlanan "Public Opinion” kitabında yer verdiği, haberin gerçeği aynen yansıtmadığı tezi, takip eden çalışmalar için önemli bir başlangıç noktası olmuştur (Şeker ve Şeker, 2011: 517). Lippman'ın çalışmasını takiben yapılan çalışmalar Liberal çoğulcu yaklaşım ve eleştirel yaklaşım çerçeveleri doğrultusunda şekillenmiştir. Basını dördüncü güç olarak gören Liberal yaklaşım, bu durumu ifadenin ve basının özgürlüğünden yola çıkarak değerlendirirken (Poyraz, 2002: 60), eleştirel yaklaşımlarda, haberin üretim sürecine etki eden ekonomik-politik unsurlar ve haber aracılığıyla yeniden üretilen ideoloji ve anlam, çalışmaların odağında yer almıştır (Şeker ve Şeker, 2011: 518- 519). Bu yaklaşımda, gerçeklik olduğu gibi yansıtılmamakta, bunun yerine yeniden oluşturulmakta, yaratılmaktadır (Poyraz, 2002: 65).

Eleştirel yaklaşım içerisinde Althusser, Devletin İdeolojik Aygıtları'ndan söz ederken, kitle iletişim araçlarını da bu aygıtlardan biri olarak nitelendirmektedir. Bu görüşe göre, egemen ideoloji medya aracılığıyla yeniden üretilmektedir (Althusser, 2003: 134.). 
İnal'ın da belirttiği gibi, medya toplumsal bir iktidarın oluşmasına hizmet etmekte, haber üretimi esnasında, profesyonel ideoloji çerçevesinde "gerçeklik" yaratılmaktadır. $\mathrm{Bu}$ bağlamda, medya dördüncü bir güç olmaktan çok, mevcut iktidar ilişkilerinin korunmasına destek veren bağımlı bir araçtır (İnal, 1996: 75).

Medya ve haber çalışmalarına eleştirel tutumu destekleyen ekonomi-politik yaklaşımın haber üretimine ilişkin görüşüne göre ise, kapitalist ekonomi ve bu sistemin dinamikleri medya içeriklerine etki etmektedir. Ekonomi-politik yaklaşım medya çalışmalarında tekelleşme ve medya kuruluşlarının finans sektörü ile olan ilişkisine odaklanmıştır (İnal, 1996: 90). Nitekim Golding ve Murdock, medya kuruluşlarınca üretilip dağıtılan içeriğin meta olduğunu öne sürmüşlerdir. Bu durumda medya kuruluşları da ekonomik değeri olan metalar üreten ticari kuruluşlar olarak kabul edilmektedir. Bu görüş, metaların, üretim koşullarını ve sürecini, ekonomik değerlerine ilişkilendirmektedir (Golding ve Murdock'tan aktaran Aydın, 2013: 43).

Öte yandan, Herman ve Chomsky (2004), haber üretimine etki eden beş süzgeci tanımlamaktadırlar. Bunlar, medya firmasının büyüklüğü, tekelleşmiş yapısı ve karçıkar ilişkileri, temel gelir kaynağı olan reklamcılık, medyanın hükümet ve iş çevreleriyle olan ilişkisi ve onların sağladığı bilgi kaynağı, medyayı disiplin altına almak için yapılan sert eleştiriler ve son olarak "ulusal bir din ve bir denetleme mekanizması olan antikomünizm" olarak sıralanmıştır.

Haber üretim sürecine yönelik eleştirel yaklaşımlarda ekonomik belirleyicilerin yanı sıra, özellikle 1970'lerden sonra gündeme gelen kuramsal gelişmeler sonucunda habere yönelik iki önemli olgu araştırmaların odağı olmuştur: ideoloji ve söylem. Bu alanda yapılan çalışmaların, sonucunda haberin söylem olarak ele alınışı hususu yaygın bir görüş haline gelmiştir (İnal, 1996: 29). Bu görüşe göre, bir haber için, pek çok farklı söylem kullanmak mümkün olabilmektedir. Burada, söylemin şeklini belirleyen faktörler dikkate alınmaktadır. Söylem sahibinin ideolojik yapısı, ileti aracı, bu aracın ideolojik yapısı ve tabii hedeflenen kitle, bu sürece etki eden faktörlerin başında gelmektedir (Devran, 2010: 118).

Özellikle 1970 ve 1980’li yıllarda Birmingham Çağdaş Kültürel Çalışmalar Merkezi dilbilimsel çalışmalarla, ideoloji, dil ve özneyi tanımlamış (İnal, 1996: 42-43), medyanın "elit iktidarının kurumsal, söylemsel ve ideolojik açıdan yeniden üretim merkezi" olduğu kabulüyle, metinlerde üretilen anlamları eleştirel bakış açısıyla incelemiştir. Kültürel çalışmaların medya alanındaki en önemli temsilcilerinden Stuart Hall'ün medya yaklaşımına göre, haber gerçeği birebir yansıtmamakta, belli bir kesimin çıkarları doğrultusunda inşa edilmiş bir içeriği temsil etmektedir (Özer, 2011: 48-49). Ancak, Çam (2008: 215)'ın da belirttiği gibi, sunulan gerçekliğin tümüyle kurgusal olma durumu söz konusu değildir. Sözü edilen durum, aktarılmak istenen içeriğin "anlaşılır" olması adına, medyanın bu aktarım sırasında yaptığı anlamlandırma çalışmasından ibarettir. Bu anlamlandırma yapılırken, İnceoğlu ve Çomak (2009: 35)'ın belirttiği gibi seçilen sözcükler, konuşma biçimi, anlatım gibi unsurlar söylemin oluşmasındaki önemli etkenlerdir. Dil ile oluşan söylemde, ideolojiler de kendilerini bu yolla ifade etmektedirler.

Haberin söylem olduğu görüşünde, gerçeklikler ideolojiler aracılığıyla üretilmekte, dolayısıyla iktidar/güç ilişkileri kurulmaktadır (Özer, 2011: 48). Hall, medya aracılığıyla 
kurulan "egemen ideoloji" kavramının altını çizmektedir (Hall'den aktaran İnal, 1996: 91). Bu bağlamda Hall ve arkadaşları, "Krizlerin Denetimi" (1978), orijinal adıyla "Policing the crisis" başlıklı çalışmalarında medyanın haber üretimi ile ilgili şu açıklamaya yer vermişlerdir:

"Medya, haberleri sadece oluşturmakla kalmaz, ne de yalnızca "egemen sınıfın" ideolojisini komplovari bir moda şeklinde aktarmaz. Aslında, biz, eleştirel bir bakış açısıyla, medyanın, çoğunlukla, haber olaylarının "ilk tanımlayıcıları" olmadıklarını ifade etmiştik: ama iktidarla olan yapısal ilişkileri, hak olarak medyaya ayrıcalıklı erişimi olan"akredite kaynaklar"ın tanımlarını yeniden üretmek konusunda, kendilerine ikincil, fakat hayati bir rol bahşetmektedir. $\mathrm{Bu}$ bakış açısına göre, haber üretim anında, medya, birincil tanımlayıcılara yapısal/yapılandırımış bir bağlılık ile konumlanmıştır" (1978: 59).

Haberin, söylemin kendisi olduğu ve iktidar/güç ilişkilerinden, ideolojiden bağımsız olmadığı kanaati, iletişim araştırmaları için geliştirilen yöntemler arasında, söylem analizinin yaygın şekilde kullanılmaya başlanmasıyla paralel şekilde kabul görmüştür (İnal, 1996: 31). Hollandalı dilbilimci Teun A. Van Dijk, haberin ideolojik söylem olduğu kabulüyle, haber araştırmalarına yön veren söylem analizi yöntemiyle metindeki söylemsel yapının incelenmesi gerektiğini savunmaktadır. Van Dijk'a göre haber bir tür değil, bir söylemdir. Hall haberin içerisinde egemen söylemin yeniden üretildiği görüşünü öne sürerken, Van Dijk, haberin söyleminin egemen söylemin bir ürünü olduğunu kabul etmektedir. İnal (1996: 97)'ın da ifade ettiği gibi, "her ikisinde de vurgulanan, haberin söyleminin egemen söylemlerden, yani güç/iktidar sahibi kurum ve kuruluşların söylemlerinden bağımsız olmadığıdır”. Söylem analizi ise, metnin oluştuğu bağlamı, güç/iktidar ilişkilerini değerlendirerek incelemektedir (Kula, 2002:191).

Haber metni söylemi üzerine çalışan Van Dijk, söylem içerisinde ifade bulan ideolojiyi "ideolojik çözümleme kategorileri” ile metni ayrıntılı olarak analiz ederek incelemektedir (Van Dijk, 2003: 54-58).Medyadaki söylemin, iktidar söyleminin yeniden üretiminde neyin nasıl söyleneceğine karar verilerek oluşturulduğunu belirten Van Dijk, haber kaynaklarından başlıklara kadar kullanılan içeriğin seçildiğini belirtmektedir. Bu durumda, haberin anlamını ve barındırdığı ideolojisini, haberin temin edildiği kaynaklarla olan ilişkiler, yapılan alıntılar, başlıklar, haberin sunuluş şekli ve ürettiği çağrışımlar oluşturmaktadır (1999: 367-375).

\section{Charlie Hebdo Saldırısının Basına Yansımaları}

Bu bölümde, 07 Ocak 2015 tarihinde, yerel saat ile 11.30 sıralarında, Fransa'nın önde gelen hiciv dergisi Charlie Hebdo'nun Paris'te bulunan ofisine düzenlenen terör saldırısını konu alan Türkiye'den üç, Fransa'dan üç gazete haberi analiz edilmiştir. İlkin çalışmada kullanılan söylem analizi yöntemine değinilmekte, sonrasında yaşanan saldırı hakkında bilgi verilmektedir. Son olarak, seçilen haberlerin analiz sonuçları paylaşılmaktadır.

\subsection{Yöntem}

Çalışma kapsamında incelenen haber metinlerinin cümle yapıları, sözcük seçimleri, başlıkları ve ele aldıkları konular, Teun A. Van Dijk'ın eleştirel söylem çözümlemesi 
yöntemine başvurularak incelenmiştir. Söz konusu haberlere gazetelerin web sitelerinden ulaşılmıştır. Farklı siyasi görüşlere sahip gazetelerden seçilen haberler olayın gerçekleştiği güne ait olup, özellikle olayın ilk duyuruluş şeklini ele almaktadır. Buna göre seçilen gazeteler, Türkiye'den aşırı sağ görüşü temsil eden Yeni Akit, sol görüşü temsil eden BirGün ile daha merkezi bir yapıya sahip olan Hürriyet gazeteleridir. Fransa basınından tercih edilen üç gazete ise, merkez sol görüşten Le Monde, sağ görüşten Le Figaro, Katolik kilisesinin ideolojisini temsil eden La Croix gazeteleridir. Ülke olarak Fransa ve Türkiye'nin seçilmesinin nedeni ise, Türkiye'nin Müslüman bir ülke olması, Fransa'nın ise saldırının gerçekleştiği ülke olmasıdır.

Araştırmada kullanılan ideolojik söylem çözümlemesi yöntemi, ideolojik öğelerin dilin yapısı içine yerleştirildiği görüşünden yola çıkmaktadır ve bu öğelerin açık şekilde görünemediği için belli bir sistematik içerisinde eleştirel biçimde çözümlenmesi gerektiğini ileri sürmektedir. Bu yöntem yardımıyla, metnin içine gizlenmiş öğelerle, toplumsal eşitsizliklerin yeniden üretilişine tanık olunmaktadır (Özer, 2008: 400). Umunç (2013: 307)'un da ifade ettiği gibi;

"Söylem çözümlemesinin, içerik çözümlemesinden en önemli farkı, metin içindeki egemen söylemin nasıl inşa edildiğinin ortaya konmasıdır. Eleştirel söylem analizi, öncelikle sosyal ve politik bağlamda konuşma ve metine dayandırılan ve yeniden üretilen kamusallaşmış eşitsizlik, egemenlik ve toplumsal güç kullanımı yollarına çalışan analitiksel söylem araştırmasının bir türüdür".

Van Dijk'ın ideolojik söylem analizinin temelinde "biz-onlar" ayrımı bulunmaktadır. Kendimizden olana olumluluk, onlardan olana ise olumsuzluk yükleyen "biz-onlar" ayrımı ile medya metinlerinde bizden olmayana yönelik hoşgörüsüz yaklaşım ve ırkçılık duyguları tetiklenmekte ve beslenmektedir (Durna ve Kubilay, 2010: 70).

Van Dijk söylemin üç temel özelliğinden söz etmektedir. Bunlar, "cümle yapıları, anlamları ve konuşma eylemleri"dir. Ancak Van Dijk'a göre söylem, sadece cümlelerdeki anlamları ve sözcük dizimlerini çözümleyerek görülemeyecek farklı derin anlamlar barındırmaktadır. Bu nedenle söylem incelenirken "sesler, sözcükler, cümle kalıpları ve anlamları"nı kapsayan mikro düzeyde bir analizin yanı sıra, tüm söylemi daha bütünsel ve "global" düzeyde ele alan, Van Dijk'ın "makro düzey" olarak adlandırdığı bir çalışma yapılması gerekmektedir. Bu aşamada, birbirinden bağımsız cümlelerin, ayrı ayrı anlamlarına bakılarak anlaşılamayacak, söylem metninin konusunu yansıtan bir anlam bütünü önem kazanmaktadır (Van Dijk, 1988: 26).Söylem analizini mikro ve makro düzey olarak adlandırdığı bu iki aşamada gerçekleştiren Van Dijk'ın yöntemiyle haber metni de detaylı bir nitel analizle incelenebilmektedir. Makro düzeyde yapılan çözümlemede metnin sunduğu konulara, ana temasına, "haberin başlıkları, alt başlıkları, giriş ve spot bölümleri" incelenerek "tematik" yani anlamsal bir analiz yapılarak ulaşılmaktadır. Yine makro aşama dâhilinde yapılan "şematik" analizde ise haberin arka planına bakılmakta ve bağlamı incelenmektedir, sonuçlara ve kaynaklara değinerek yorumlara yer verilmektedir. Yöntemin bir diğer aşaması olan mikro düzeydeki incelemede ise daha detaylı biçimde "cümle yapıları" ve aralarındaki anlamsal bağlantılar, tercih edilen sözcükler ve metnin "retoriği”" ele alınmaktadır (Van Dijk, 1988a:13-19). 


\subsection{Charlie Hebdo'ya Saldırı}

07 Ocak 2015 tarihinde, saldırının sorumlusu oldukları belirlenen Said ve Cherif Kouachi kardeşler, yerel saatle 11.30'da, Fransız hiciv dergisi Charlie Hebdo'nun Paris'teki ofisine silahlı saldırıda bulunmuştur. 12 kişinin hayatını kaybettiği saldırının sorumluları kendilerini El Kaide'nin Yemen koluna ait olarak tanımlamışlardır. Fransa'da ve Dünya'da büyük ses getiren, basında uzun süre yer alan saldırı, 1989 yılında Christian Dornier tarafından düzenlenen saldırıdan bu yana, Fransa'da gerçekleştirilen en fazla kayıplı saldırı olarak sıklıkla gündeme gelmiştir. Bu ilk saldırıyı takiben, ulusal yas ilan edilen ertesi gün, Kouachi kardeşlerin bir yakını olan Amedy Coulibaly, 26 yaşındaki bir kadın polis memurunun ölümüne sebep olmuştur. Son olarak 09 Ocak Cuma günü, Kouachi kardeşler ve Coulibaly, İle- De-France bölgesinin iki farklı adresinde gerçekleştirdikleri girişimlerle 4 kişiyi daha öldürmüşlerdir. Tüm bu saldırıların ardından, yine 09 Ocak günü, üç saldırgan da, jandarma ve polislerden oluşan özel ekipler tarafından öldürülerek durdurulmuşlardır. (http://atelier.leparisien. fr, erişim tarihi: 01.06.2015)

Charlie Hebdo saldırısının nedeni, derginin Hz. Muhammed'i konu alan karikatürü olarak belirtilirken, dergi çalışmalarına, yayınlarına, aynı şekilde devam edeceğini duyurmuştur. Hayatını kaybeden gazeteciler ve karikatüristler için, dünyanın çeşitli ülkelerinde basının ifade özgürlüğünü savunan yürüyüşler ve etkinlikler düzenlenmiştir. Yaşanan olayların ardından, zihinlerde yer eden "Je Suis Charlie” (Ben Charlie'yim) sloganı ise bir tür sembol haline gelmiştir.

Charlie Hebdo saldırısının bir başka boyutu ise, olaylar sonrası yaşanan tartışmalar ve görüş ayrılıkları olmuştur. Büyük bir çoğunluk, özellikle basında, olaylara ifade özgürlüğü ve basın özgürlüğü penceresinden bakarken, bir kesim saldırının nedeni olarak sunulan karikatürlerle dini inançlara saygısızlık yapıldığı tepkisi ile olaylara yaklaşmıştır. Bu yaklaşım farklılığı medyada da yansımalarını bulmuştur.

\subsection{Haber Analizleri}

$\mathrm{Bu}$ bölümde, Türk ve Fransız basınından seçilen 6 gazetenin olayın meydana geldiği gün yayınladıkları haber metinleri eleştirel söylem çözümlemesi yöntemiyle incelenmiştir.

\subsubsection{Yeni Akit}

Siyasi ideoloji olarak aşırı sağ görüşü temsil eden Yeni Akit Gazetesi'nin düzenlenen terör saldırısını duyurduğu haberinde (www.yeniakit.com.tr, 2015) kullanılan başlığa, sözcük seçimlerine ve cümle yapılarına baktığımızda elde edilen sonuçlar şu şekildedir: "Paris'te küstah mizah dergisine saldırı" (www.yeniakit.com.tr)

Haberin başlığında kullanılan "küstah" nitelendirmesi, gazetenin ideolojik olarak olaya karşı kendini konumlandırma şeklini açık şekilde göstermektedir. Gazete kendisini daha haberin en başında hiciv dergisinin karşısında konumlandırmaktadır ve dergiye olumsuz bir nitelendirme ile gönderme yapmaktadır. Başlıkta saldırıya ait herhangi bir detay verilmemiştir. Ölen kişi sayısı veya saldırganların kimler olduğuna dair herhangi bir bilgi bulunmamaktadır. Van Dijk'ın söylem analizi yöntemine bakıldığında, "onlar" hakkındaki olumlu bilgileri saklamak, bir anlamda karşı taraf olarak konumlandırılan 
kişilerin mağduriyetini ve haklı yönlerini söylememek, saklamak da metinde gizlenen ideolojiyi gösteren stratejik bir tutumdur. Bu başıkta da bu durum açıkça görülebilmektedir.

"Fransa'da yayınlanan mizah dergisi Charlie Hebdo'ya saldırı düzenlendi." (www. yeniakit.com.tr)

Haber metninin ilk cümlesi edilgen bir cümledir. Bu şekilde saldırıyı düzenleyenlerin kim olduğu bilgisi gizli tutulmaktadır. Oysaki haberin yayınlandığı saatlerde diğer pek çok yayın, saldırının bir terör saldırısı olduğu ve Müslüman iki örgüt üyesi tarafından "cihad" niteliğinde yapıldığı bilgisini vermiştir. Bu haberde, "terör" sözcüğüne yer verilmemiştir, İslami terör olabileceğinin tartışıldığı saatlerde, bu bilgi tamamen yok sayılmıştır. Bu durum da gazetenin siyasi duruşu ile tutarlııı göstermektedir.

"Henüz doğrulanmamış gelen ilk bilgilere göre otomatik silahlarla gerçekleşen saldırıda 12 kişi hayatını kaybetti." (www.yeniakit.com.tr)

Haber metninin ikinci cümlesinde, "doğrulanmamış" sözcüğü ile kesinlik olmadığı vurgulanmakta ve ölenlerden "kişi” ifadesi ile bahsedilmektedir. Söz konusu saldırı bir dergiye düzenlenmiştir, dolayısıyla oradaki çalışanlar Fransa'nın önde gelen gazetecileri ve karikatüristleridir. Ancak, gazete ideolojisi itibariyle, başlıkta da bildirdiği gibi derginin karşıt görüşünde konumlandığı için bu kişiler hakkında bilgiye yer vermemeyi tercih etmiştir. Haberin devamında da yine ölenlerden "kişi" olarak söz edilmektedir.

“Fransız televizyon kanalı iTele, Charlie Hebdo'nun Paris'teki merkezine, 3 kişinin silahlı saldırıda bulunduğunu ve en az 12 kişinin hayatını kaybettiğini, 5 kişinin de yaralandığını bildirdi."(www.yeniakit.com.tr)

"Dergi, Peygamberimiz Hz. Muhammed ile ilgili küstah karikatürleri nedeniyle tepki çekmişti." (www.yeniakit.com.tr)

Haberin başında saldırıyı duyururken din ve İslam ile ilişkili herhangi bir bilgiye yer verilmezken, ilk bilgilerin ardından kurulan bu cümlede gazete saldırıya maruz kalan dergiyi suçlar nitelikte "küstah" nitelendirmesini yinelemekte ve "biz-onlar" karşıtığını kurmaktadır. "Peygamberimiz Hz. Muhammed" ile "bizim" olana dikkat çekilmiş ve bizim olan ile ilgili yapılanın yanlış olduğu "küstah" sözcüğüyle vurgulanmak istenmiştir. Haberin, derginin geçmişine ilişkin verdiği bilgiyle, saldırının zaten haklı sebepten olduğu, geçmişte de benzer nedenle derginin tepki çekmiş olduğuna değinilmektedir.

"Fransız mizah dergisi Charlie Hebdo, Kasım 2011'de "Hz. Muhammed" karikatürleri yayımlamış, ardından başlayan protesto gösterilerinde derginin editoryal işlerinin yürütüldüğü Parisıteki merkezi ateşe verilmişti. Dergi buna rağmen, 19 Eylül 2012,de $\mathrm{Hz}$. Muhammed'e hakaret içeren karikatürler yayımlamış ve pek çok ülkede büyük tepkilerle karşılaşmıştı."(www.yeniakit.com.tr)

Bu paragrafta yine artalan bilgisine yer verilmiş ancak bu bilgi derginin genel yapısı, editörleri vs. hakkında değil, geçmişte dergiye düzenlenen saldırılarla ilgilidir. 2011 yılında düzenlenen saldırıdan bahsederken "Hz Muhammed" tırnak içinde verilmiştir. 
Takip eden cümlede ise "buna rağmen" ifadesiyle, "bu durum bir kez başlarına geldiği halde, sonucu bile bile, karikatür girişimini tekrarlamışlar" anlamı verilmek istenmiştir.

“Fransa'nın başkenti Paris'te yayınlanan ve Hz. Muhammed'in karikatürünü yayınlayınca büyük tepki çeken 'Charlie Hebdo' dergisinin Paris'in 11'inci Bölgesi'nde bulunan binaya saat 11.30 sıralarında giren 3 kişinin Kalaşnikof silahlarla çalışanların üzerine ateş açtığı iddia edildi." (www.yeniakit.com.tr)

"Büyük tepki" ifadesi bu cümlede yeniden vurgulanmıştır. Ölen gazetecilerden ise "çalışanlar" olarak söz edilmesi ve saldırıya ilişkin daha detaylı bilgi vermek yerine, $\mathrm{Hz}$. Muhammed'in karikatürleri nedeniyle derginin tepki topluyor olması, yani saldırının teröristler tarafından ele alınan gerekçelerinin vurgulanması, gazete açısından bilinçli, ideolojik bir tercihtir.

\subsubsection{Hürriyet Gazetesi}

İdeolojik olarak daha merkezi bir duruş sergileyen Hürriyet Gazetesi'nde saldııının olduğu günden bu yana çok sayıda haber yer almıştır. Bu araştırmada, diğer gazeteler için olduğu gibi, Hürriyet Gazetesi'nden de olayın gerçekleştiği 7 Ocak 2015 tarihinde yayınlanan ve konuya ilişkin ilk genel bilgilerin verildiği haber metni (www.hurriyet.com. tr) ele alınmıştır.

"Paris'te Charlie Hebdo dergisine silahlı saldırı"(www.hurriyet.com.tr)

Haberin başlığı sade ve genel bir niteliktedir. Saldıranların kimler olduğu belirtilmemiştir.

“Fransa'nın başkenti Paris'te mizah dergisi Charlie Hebdo'nun merkezine silahlı kişilerce saldırıldı." (www.hurriyet.com.tr)

Haberin ilk cümlesi edilgen yapıdadır. VanDijk'ın söylem analizi yöntemine göre bu durum haber metninin kendini hangi safta konumlandırdığına ilişkin bilgi vermektedir. Burada, gazetenin kendisini olayın dışında tutarak, daha çok tarafsız bir ifade kullanmaya çalıştığı görülmektedir.

“En az 12 kişinin ölümüne neden olan saldırganlar kaçtı.” (www.hurriyet.com.tr)

Ölen kişi sayısı belirtilirken, "en az" denmesi bu sayısının artabileceğine işaret etmektedir. Bu durumda sayıyı az ya da çok göstermek gibi bir kaygı olmaksızın belirsizlik vurgulanmaktadır.

"Derginin 'Coco' adını kullanan çizeri, yaşananları anlattı ve "Giriş kodunu girdim ve kapıyı ben açtım. Beş dakika sürdü” ifadelerini kullandı." (www.hurriyet.com.tr)

Derginin kendi çalışanlarından birinin ifadelerine, yani saldırıya uğrayan tarafın doğrudan sözlerine haberin girişinde yer veriliyor olması, gazetenin kendisini dergi ile birlikte "biz" olarak konumlandırdığını göstermektedir.

“Derginin Paris'in 11 'inci bölgesindeki Nicolas Apper Caddesi'nde bulunan merkezine saat 11.30 sularında (TSi 12.30) silahlı en az iki kişi tarafından saldırı düzenlendi. Saldırıda ikisi polis, en az 12 kişinin yaşamını yitirdiği bildirildi."(www.hurriyet.com.tr) 
"Saldırıda dördü ağır 11 kişinin yaralandığı belirtildi. Ilerleyen saatlerde Içişleri Bakanı Bernard Cazeneuve saldırıyı düzenleyenlerin üç kişi olduklarını söyledi. "(www.hurriyet. com.tr)

Takip eden cümlelerde "en az" ifadesi tekrarlanmıştır. Bu vurgunun, olayın ciddiyetini, daha da büyük sonuçları olabileceğini belirtmek için kullanıldığı düşünülebilir. Öte yandan, Fransa İçişleri Bakanı'nın ifadesine yer verilmesi, Hürriyet Gazetesi'nin resmi kaynaklara dayanan ve gerçekliği konusunda şüpheye yer bırakmayan bilgiler vermeyi tercih ettiğini göstermektedir.

"Öldürülen iki polisin, saldırı anında dergide olan Genel Yayın Yönetmeni StephaneCharbonnier'yi korumakta oldukları belirtildi. Ölüm tehditleri alan Charbonnier, uzun süredir polis tarafından korunuyordu."(www.hurriyet.com.tr)

"Kalaşnikof ve roketatarlı saldırganlar, kaçarken olay yerinin yakınında bulunan bir polis aracını da hedef aldı. Görgü tanıkları, saldırı sırasında en az 30 silah sesi duyduklarını belirtti"

\section{“Fransa En Önemli Karikatüristlerini Kaybetti”(www.hurriyet.com.tr)}

Haberde verilen alt başlıkta ölenlerin profesyonel kimlikleri ön plana çıkarılmış, Fransa'nın özne olarak kullanıldığı başlık etken cümle yapısıyla kurulmuştur. "En önemli" ve "kaybetti" ifadeleriyle yaşanan durumun trajik yönüne değinilmiştir. Bu olayın Fransa Devleti için bir kayıp olduğunun vurgulanması, saldırganların yaptığı eylemin "olumsuz" sonucunun altını çizmektedir.

"Fransa basınında yer alan haberlerde derginin genel yayın yönetmeni Stephane Charbonnier ve Jean Cabut'nün de aralarında bulunduğu Fransa'nın en önemli karikatüristleriölenler arasında yer alıyor. Uzun süredirölüm tehditleri alan Charbonnier, polis korumasında yaşıyordu."(www.hurriyet.com.tr)

"Fransız ekonomi uzmanı, yazar, gazeteci ve aynı zamanda Charlie Hebdo'nun ortaklarından olan Bernard Maris de saldırıda yaşamını yitirdi."(www.hurriyet.com.tr)

Olaya ilişkin detayların verildiği diğer cümlelerde ölenlerin kimliklerine odaklanılmış, önemli değerler olduklarının altı çizilmiştir. Genel yayın yönetmeninin uzun süredir ölüm tehdidi alıyor olmasının belirtilmesi de, ölenlerin haklılığının altını çizer niteliktedir.

"Yazı İşleri Toplantısı Vardı"

"Le Monde gazetesi, Charlie Hebdo'dan bir gazetecinin verdiği bilgiye dayanarak saldırının olduğu saatlerde dergide yazı işleri toplantısının yapıldığını ve saldırganların büyük olasılıkla bunu bildiğini söyledi. Gazetenin haberinde "Haftanın diğer günlerinde dergide çok fazla kişi olmaz, bunu biliyorlardı" ifadeleri yer aldı."(www.hurriyet.com.tr)

$\mathrm{Bu}$ alt başlık ile "işini yapan", "kendi halinde görevini yerine getiren" inşaların öldürüldüğüne vurgu yapılmak istenmiştir. Saldırı anında dergidekilerin başlarına geleceklerden habersiz bir şekilde toplantı yapıyor olmalarına vurgunun yapılması, diğer taraftan başlığın altında verilen bilgilerde saldırganların bunu "büyük olasılıkla" 
bildiğini,dolayısıyla saldırının "planlı" olduğunu ifade eden Le Monde Gazetesi görüşüne yer verilmesi de, Hürriyet Gazetesi'nin,LeMonde ile ortak görüşte olduğunu ve bu düşünceye destek verdiğini göstermektedir.

\subsubsection{Birgün Gazetesi}

Araştırma kapsamında Türkiye'den seçilen bir diğer gazete sol görüşe sahip BirGün gazetesidir. Gazetenin 07 Ocak 2015 tarihinde yayınlanan haber metni (www.birgun. net, 2015) oldukça uzun ve detaylıdır. Bu durum diğer gazetelerle kıyaslandığında dikkat çekici bulunmuştur.

"Charlie Hebdo'ya saldırı: Charb, Cabu, Wolinski ve Tignous yaşamını yitirdi"(www. birgun.net)

Başlıkta cümlenin etken biçimde kurulup, özne olarak ölen karikatürist ve gazetecilerin isimlerinin verilmesi, gazetenin kendisini dergi cephesinde konumlandırdığını göstermektedir. Tek tek isimlerinin sayılması ve "yaşamını yitirdi" ifadesiyle yumuşak bir tonda saygı ve üzüntü barındıran bir söylem tercih edilmesi, bu kişilere BirGün gazetesi tarafından verilen değeri gösterir niteliktedir.

"Daha önce Muhammed peygamberle ilgili karikatür yayımladıkları gerekçesiyle ırkçı saldırıların hedefinde olan Fransız mizah dergisi Charlie Hebdo'nun Paris'teki bürosuna bir silahlı saldırı düzenlendi." (www.birgun.net)

Haberin ilk cümlesinde "Muhammed Peygamber" nitelemesi, İslam camiası tarafından "Hz." sıfatı kullanılarak yapılan nitelendirmeye ters düşmektedir. Haberde, "herhangi bir" peygamberden farksız, BirGün gazetesi açısından öneme sahip olmayan bir kişiden söz ediliyormuşçasına bir ifade kullanılmıştır. Aynı cümlede yer alan "gerekçe" sözcüğü saldırıyı yapanların öne sürdükleri nedenin geçersizliğine vurgu yapmakta, "ırkçı" nitelendirmesi ise saldırıyı yapan "onlar" tarafı için kullanılan olumsuz bir ifade özelliği taşımaktadır.

"Saldırıda 10'u gazeteci, ikisi polis olmak üzere 12 kişinin yaşamını yitirdiği belirtildi. Saldırıda en az 10 kişinin yaralandığı ve yaralılardan 5 kişinin durumunun kritik olduğu kaydedildi."(www.birgun.net)

Bu cümlede ölenlerin gazeteci ve polis olmalarına vurgu yapılmıştır. "en az" ifadeleri yine saldırının büyüklüğünü destekler niteliktedir. Yararıların durumu ile ilgili verilen bilginin de içeriğine bakıldığında, yine kayıp sayısının artabileceği intimalinin altı çizilmektedir. Daha detaylı bilgi vermek, özellikle de durumun vahametini gösterecek ayrıntılarla haberi desteklemek, gazetenin ideolojik yönelimine uygun bir tercihtir.

"Fransa Içişleri Bakanı Bernard Cazeneuve, saldırıyı üç kişinin gerçekleştirdiğini tespit ettiklerini açıkladı. Cazeneuve, "Bu üç suçluyu yakalayacağız" dedi." (www.birgun.net)

Fransa İçişleri Bakanı'nın sözlerine tırnak içerisinde yer verilmiş olması gazetenin yine kendini konumlandırışı bakımından öneme sahiptir. Fransa'ya karşı düzenlenen bir saldırı olduğundan, Fransa'nın bir devlet yetkilisine vurgu yapılarak ifadelerine yer verilmesi, VanDijk'ın söylem analizi tekniğine göre de gazetenin kendini konumlandırdığı tarafın bir göstergesidir. 
"Fransız basını, saldırıda ülkenin en önemli karikatüristleri arasında yer alan derginin genel yayın yönetmeni Stephane Charbonnier (Charb) ile çizer Jean Cabut'nun (Cabu) öldügünü duyurdu. Georges Wolinski ve 'Tignous'olarak da bilinen Bernard Verlhac'nın da ölenler arasında yer aldığı kaydedildi. Ekonomist, yazar Bernard Maris'ninde yaşamını yitirdiği açıklandı." (www.birgun.net)

Ölen kişilerin kimlik bilgileri ve bazılarının kariyerlerindeki konumlarıyla ilgili yazılanlar, pek çok gazetenin, o gün o saatlerde henüz vermediği veya hiç vermeyeceği bilgilerdir. Haber incelendiğinde içerikteki karşıtlıklar göze çarpmaktadır. Yaşamını yitirenler belli sosyal ve ekonomik sınıflardan gelen, itibarlı, tanınmış kişilerken, saldırıyı düzenleyenler "terörist", "saldırgan" ve "katil"dirler ve böyle "değerli" kimseleri öldürmüşlerdir.

“Görgü tanıkları, siyah kapüşonlu üç kişinin Kalaşnikoflarla dergi binasına girdiğini ve etrafa ateş açtığını söyledi. Görgü tanıkları arasında saldırganların ateş açarken 'Allahuekber've 'Peygamberin intikamını alıyoruz' diye bağırdığını öne sürenler de yer aldı." (www.birgun.net)

Saldırı anına dair betimleme yapılan bu bölümde özellikle tırnak içerisinde saldırganların ateş açtıkları sırada tanık olunan ifadelerine yer verilmiştir. Eylem betimlenirken "kalaşnikof" ile "Allahuekber" ve "peygamberin intikamını alıyoruz" söylemleri aynı paragrafta, aynı kişiler için kullanılmıştır. İslam dini için önemli bir ifade olan "Allahuekber"inkalaşnikof kullanan saldırganlarca söyleniyor olması, İslamiyet ve terör ilişkisine vurgu yapmaktadır. Ayrıca, "peygamberin intikamını alıyoruz" söyleminin belirtilmesi de terör saldırısını İslam dinine ve peygamberine mal eden bir yaklaşımdır.

"Saldırganların siyah bir araçla olay yerinden uzaklaştığı, kaçarken bir polis aracına ateş açtığı ve iki polisin de bu esnada yaralandığı ifade edildi. Daha sonra saldırganlar bir yurttaşın aracını zorla ele geçirdi ve bununla yola devam etti." (www.birgun.net)

"Polis sözcüsü RoccoContento ise, saldırganlara bir kişinin daha katıldığını ve Porte de Pantin yakınlarında 'dördüncü' bir kişi tarafından kullanılan araçla kaçmaya devam ettiklerini açıkladı. Polisle saldırganlar arasındaki kovalamaca Paris'in doğusunda devam ediyor." (www.birgun.net)

"Tüm Paris'te 3 binden fazla polisin alarma geçirildiği kaydedildi."(www.birgun.net) Saldırganların polisle aralarında geçen çatışmayı ele alan ve detaylandıran bu kısımda, tüm Fransız halkının güvenliği için hayati öneme sahip polislerin de hayatlarını kaybettikleri ve mücadelenin devam ettiği vurgulanmıştır. Polis sözcüsünün ifadesine yer verilmesi, haberdeki bilgi kaynağının güvenilirliğini destekleyecek bir öğe olarak kullanılmıştır. Çatışma tasvir edilmekte, tüm Fransız polisinin bu tehlikeye karşı seferber olduğu, dolayısıyla yaşanan olayın dünyanın önde gelen demokratik ülkelerinden birini hangi ölçüde tehdit ettiğinin altı çizilmektedir.

Haberin devamında artarda gelen başlıklar şöyledir:

"Savcı: iki Saldırgan Binaya Girdi, Diğeri Dışarıdaydı" (www.birgun.net) “Hollande Olay Yerinde: Kimse Özgürlüğe Saldıramaz"

"Cameron: Mide Bulandırıcı"

"Saray'dan Kınama, Bm'den Birlik Çağrısı" 
Yukarıda art arda gelen 4 başlıkta ve içeriklerinde olayın uluslararası bağlamdaki yankısı aktarılmıştır. Öncelikle Fransa Cumhurbaşkanı ve Paris Savcısı'nın açıklamaları, akabinde ise Ingiltere, Amerika ve Birleşmiş Milletler 'in saldırıya ilişkin düşünceleri yer almaktadır. Bu ifadelere genel olarak bakıldığında, ifadeleri kullananların ortak söylemleri saldırıyı kınadıkları ve karşısında oldukları yönündedir. Tırnak içerisinde doğrudan verilen ifadeler birleştirildiğinde saldırının planlı olduğu, teröristlerce gerçekleştirildiği, özgürlüğe, özellikle ifade özgürlüğüne yönelik olduğu sonucu çıkmaktadır. Öte yandan, Cameron'ın söyleminde yer alan "mide bulandırıcı" ifadesi başlığa da taşınmıştır. Burada, Dünya'nın önde gelen güçlerini temsil eden kişilerin yaşananları ne denli kınadıkları öne çıkarılmak istenmiştir. Bu vurgu yapılırken de söylemlerin doğrudan ve tırnak içerisinde verilmesi, Van Dijk'ın (1988) tespitine göre haberi yapanların kendi yorumlarını katmadan olayı yorumlamalarını sağlamaktadır. Dolayısıyla, BirGün gazetesinin yaşananları kınadığı, ifade ve basın özgürlüğünü hedef alan terörist bir saldırı olarak gördüğü söylenebilir. Bu yorumların uluslararası siyasette sözü geçen önde gelen isimler tarafından söylenmesi de görüşlerin geçerliliğini güçlendirmektedir. Dikkat çeken bir diğer ortak mesaj ise "birlik olmak" üzerine kurulmuştur. Bu durum, başlıkların altında yer alan şu ifadelerle görülmektedir;

"Ingiltere Başbakanı David Cameron da saldırının ardından Twitter hesabından "Paris'teki cinayetler mide bulandırıcı. Teröre karşı savaşta ve ifade özgürlüğünü savunma çabalarında Fransız halkının yanındayız" diye yazdı."

- $\quad$ "Beyaz Saray da saldırıyı kınayan bir açıklama yayımladı. Başkan Barack Obama'nın sözcüsü, "ABD’nin yaşamını yitiren kişilerin aileleri ve yakınlarıyla dayanışma içinde olduğunu" söyledi.

- $\quad$ Birleşmiş Milletler Genel Sekreteri Ban Ki-moon ise "Bu, demokrasi, basın ve ifade özgürlüğüne doğrudan bir saldırıdır. Saldırı bizi bölmeyi amaçlıyor. Bu tuzağa düşmeyelim, şimdi birlik zamanıdır" dedi." (www.birgun.net)

Buna göre iki taraf olduğu, taraflardan birinin güçlüyü ve yöneteni temsil ettiği, diğer tarafın ise demokrasi ve özgürlük karşıtı, masum insanların canına kıyan teröristler olduğu söylenebilir.

\section{“Müslüman Temsilciler Olay Yerinde: Onlar Sadece Bir Azınlık”}

“Fransa'daki Müslüman kamuoyunun önde gelen isimleri de dergi binasına giderek saldırıyı kınadı. Liderler, "Saldırı bizi de hedef aldı, hepimiz kurbanız. Onlar [saldırganlar] sadece bir azınlığı temsil ediyor" dedi.

Saldırının ardından yaşamını yitirenleri anmak ve dergiyle dayanışma göstermek için Twitter'da '\#JeSuisCharlie' (Ben Charlie'yim) etiketi açıldı ve yüzlerce destek mesajı paylaşıldı."(www.birgun.net)

$\mathrm{Bu}$ başlık altında, olayın Müslümanlara mal edilmesinin doğru olmadığını ifade eden bir aktarım vardır. Bu açıklama "Fransa'daki Müslüman kamuoyunun önde gelen isimleri" tarafından yapılmıştır. Ancak, daha önceki açıklamalarla karşılaştırıldığında, diğerlerinde şahısların isimleri birden fazla kez belirtildiği halde, bu bölümde detay verilmediği, söyleyenlerin kimlerin olduğunun belirtilmemiş olduğu görülmektedir."Müslüman liderler" şeklinde yapılan genelleme, yapılan açıklamanın etkisini de azaltan bir amaca hizmet etmektedir. 
“Salman Ruşdi: Hiciv Sanatını Korumak liçin CharlıeHebdo’nun Yanındayım” (www. birgun.net)

“Şeytan Ayetleri' kitabı nedeniyle radikal İslamcı kesimin tehditlerine maruz kalan yazar SalmanRuşdi de, Charlie Hebdo için bir destek mesajı paylaştı. Ruşdi, "(...)'inanca saygı' adeta 'inanç korkusu' olarak ifade edilebilecek bir koda dönüştü. Dinler, tüm diğer fikirlerde olduğu gibi, eleştiri, hiciv ve evet, korkusuz bir saygısızlığı hak eder" dedi." (www.birgun.net)

Salman Ruşdi'nin yukarıdaki söylemine tırnak içinde yer veren BirGün Gazetesi, yine Van Dijk'ın söylem analizi teorisine göre, olayın gazete tarafından yorumlanış şeklini göstermektedir (Van Dijk, 1988). Geçmişte "radikal İslamcı" kesimden tepki alıp, mevcut durumda bu kesimin karşı cephesinde olduğu anlaşılan bir yazarın, "dinler... korkusuz bir saygısızlığı hak eder" sözlerine yer verilerek gazete hangi fikri desteklediğini de dolaylı olarak okuyucuya aktarmaktadır. Ayrıca Salman Ruşdi'nin dergiye verdiği desteği ele alan cümlenin etkin yapısı, Ruşdi'nin söylemini güçlendirmekte ve yeniden üretmektedir.

\section{"Son Tweet, Işid Liderini Hicvediyor” (www.birgun.net)}

"Dergi, sosyal medyada en son kendini halife ilan eden IŞiD lideri Ebubekir el Bağdadi'yi hicveden bir paylaşımda bulunmuştu. Derginin "Aslında iyi dileklerimle" notuyla paylaştığı karikatürde Bağdadi "ve özellikle de sağlık" diyor.

Derginin son sayısının kapağı ise, yeni romanıyla Fransa'da büyük tartışma yaratan yazar MichelHouellebecq'in son romanını konu alıyor. Houellebecq, gelecekte İslamcı parti ile Müslüman Cumhurbaşkanı tarafından yönetilecek ve kadınların çalışmasına izin verilmeyecek bir Fransa portresi çiziyor."(www.birgun.net)

Haberin bu bölümünde derginin saldırıya uğramadan önceki son paylaşımına yer verilmektedir. Haber, bu noktaya kadar yapılan karikatürlerden dolayı ve İslam dinini konu alan, hiciv içeren içeriklerden dolayı derginin saldırıya uğramış olduğunu belirtmektedir. Bu aşamada ise Işid liderinin karikatürü ve Michel Houellebecq'in romanının dergideki yansımasını ele alarak, İslam dinini ve peygamberini savunmak amacıyla tehdit edenlerle, son sayıda yer alan,İslam terörünü ve radikal İslam'ı destekleyenleri bir tutmaktadır.

"Hollandalı Dergi de Alarma Geçti” ( www.birgun.net)

"Haber ajansı Reuters, Charlie Hebdo saldırısının ardından yine Muhammed peygamberi hicveden karikatürleri yayımlayan Hollandalı Jyllands-Posten dergisinin de alarma geçtiğini duyurdu. Derginin bağlı olduğu medya grubu JP/PolitikensHus, güvenlik önlemlerinin artırıldığını açıkladı."(www.birgun.net)

'İspanya>daki El Pais gazetesi de bomba ihbarı aldıklarını ve alarma geçtiklerini açıkladı."(www.birgun.net)

Hollandalı derginin İslam'ı hicveden, yani alaycı biçimde eleştiren, içeriğinden dolayı, kendi güvenlik önlemlerini arttırdığını aktaran metinde, Hz. Muhammed yerine, 
yine haberin başındaki gibi "Muhammed peygamber" ifadesi kullanılması dikkat çekmektedir. Bu ifadeyle gazetenin İslam karşıtı bir duruş sergilediği söylenebilir.

“Dergi Merkezi Ateşe Verilmişti” (www.birgun.net)

"Charlie Hebdo, Kasım 2011'de Muhammed karikatürleri yayımlamış, bunun ardından başlayan protestolar derginin Paris'teki merkezinin ateşe verilmesine kadar varmıştı. Bu saldırı karşısında geri adım atmayan ve ifade özgürlüğünü savunan dergi, 19 Eylül 2012 'de yine peygamberi hicveden karikatürlere yer vermişti. Dergi, 24 saat polis tarafından korunuyordu."(www.birgun.net)

Haberin sonunda yer alan, arka plan bilgisi olan bu bölüm, genellikle uzun haberlerde karşımıza çıkmaktadır. Haberin kalitesini gösteren bu bilgi "şematik uygunluğu için bir kanıt olarak kabul edilmektedir" (Şen, 2013: 169). Habere konu olan olayın aktarımını takiben geçmişte yaşanan öncü gelişmeleri, olaya bir nevi zemin hazırlayan bir çerçeve şeklinde sunmak, olayın içerisinde geliştiği bağlamda mantıklı zincir ortaya koymaktadır. Böyle bir şemayla verilen bilgilerin güvenilirliği de desteklenmektedir.

\subsubsection{Le Monde}

Fransa'nın önde gelen gazetelerinden Le Monde ideolojik olarak "merkez-sol" da yer almaktadır. 07 Ocak 2015 tarihli haber (www.lemonde.fr, 2015) incelenirken, metnin tamamı değil, özellikle ideolojik veri yansıtan bölümler ve başlıklar, önce Türkçeye çevrilmiş, sonrasında analiz edilmiştir.

"Attaquecontre «Charlie Hebdo »: Hollandeparle d'« attentatterroriste »"(www. lemonde.fr)

\section{"Charlie Hebdo"ya saldırı: Hollande"terörist girişim" olduğunu söylüyor"}

Başlığın ilk kısmında kullanılan edilgen cümle yapısı ve saldırının kimler tarafından yapıldığı bilgisinin verilmemesi, hemen ardından ikinci kısımda ise, Cumhurbaşkanının söylemi ile saldııının niteliği hakkında bilgi verilmesi, gazetenin ideolojik duruşu ile paraleldir. Merkez solda yer alan gazete, özellikle merkeze yakın oluşu nedeniyle, egemen söylemi yeniden üretmektedir. Başlıkta tırnak içerisinde gösterilen "Charlie Hebdo" ve "terörist girişim" ifadeleri, başlığı ve haberi özetler nitelikte olup, okuyucuya konuya ilişkin "bilmesi gerekeni" sunmaktadır.

"L'attaque à l'armeautomatiquequi a tuéaumoins 11 personnesausiège de Charlie Hebdomercredi 7 janvierest " un attentatterroriste, ça ne faitaucundoute », a déclaré François Hollande, quis'estrendu sur leslieux. Le président, l'airgrave, a qualifiél'attaque d'« acted'uneexceptionnellebarbarie » :

«Uneattaquevientd'êtrecommisecontre un journal - c'est-à-dire l'expression de la liberté-contredesjournalistesquiavaienttoujoursvoulumontrerqu'ilspouvaientagir, en France, pourdéfendreleursidées. II y avaitdespolicierspourlesprotége r. Ilsontétélâchementassassinés. Onzepersonnessontmortes, quatre en situationd'urgenceabsolue. Il y a 40 personnesquisontprotégées et sauves.»" (www.lemonde.fr) 
Olay yerlerine gelen François Hollande, 7 Ocak Çarşamba günü Charlie Hebdo'nun merkezinde, otomatik silahla en az 11 kişiyi öldüren saldırı için: "hiç şüphe yok, bu bir terörist girişimdir" dedi. Cumhurbaşkanı, ciddi bir halde/ endişeli bir halde saldırıyı "olağanüstü bir barbarlık hareketi” olarak nitelendirdi.

Haberin başlığında olduğu gibi, ilk bölümünde de Fransa Cumhurbaşkanı'nın söylemi haberde yeniden üretilmiştir. Söylem analizi yöntemine göre, gazete kendi görüşünü bildirmeden, başka bir kişinin yorumuyla,bu haberde söz konusu devletin en yetkili merci, konuya açıklama getiriyorsa, bu aslında o gazetenin kendi yorumu ile örtüşmektedir. Dolayısıyla, Le Monde gazetesi bu saldırıyı bir terörist girişim olarak yansıtmaktadır. Hollande'ın söylemindeki "hiç şüphe yok" ifadesine haberde yer verilmesi, açıklamaya tartışmasız bir doğruluk atfetmiştir. "en az 11 kişi” ifadesi, olayın ciddiyetine dikkat çekerken, Cumhurbaşkanı'nın "endişeli/ciddi” olduğunun belirtilmesi bu vurguyu kuvvetlendirmektedir. Cumhurbaşkanı saldırıyı kınamıştır. Haberde aktarılan bu söylem, gazetenin bu konuyla ilgili görüşünü yansıtmaktadır.

« Lesauteurs de cesactesserontpourchassésaussilongtempsquenécessairepourqu'ils puissentêtrearrêtés, traduitsdevantlesjuges, et condamnés ", a martelé M. Hollande, car « personne ne peutagir en France contrel'esprit de la République ». Le président a révéléque le plan Vigipirateavaitétérelevéauniveau « alerteattentat ».(www. lemonde.fr)

Hollande, "Bu eylemi gerçekleştirenler, yakalanabilmeleri, hâkim karşısına çıkarılabilmeleri ve ceza alabilmeleri için, ne kadar gerekiyorsa, o kadar süre takip edilecekler, çünkü kimse Fransa'nın Cumhuriyet ruhuna karşı böyle bir harekette bulunamaz. "Cumurbaşkanı "saldırı alarmı" düzeyinde Vigipirate planının oluşturulduğunu açıkladı.

Haber Hollande'ın sözleriyle devam etmektedir. Buraya kadar, olayın niteliği hakkında devletin en yetkili merciinin yorumlarını içeren haber, yine Cumhurbaşkanı'nın açıklamalarıyla devam etmektedir. Bu sözlerle Hollande, ülkesinin vatandaşlarına "her şeyin kontrol altında olduğu" çağrısını yaparken, uluslararası boyutta, tüm dünyaya Fransa'nın konumunu hatırlatmakta ve Cumhuriyet değerlerinin dokunulmazlığının altını çizerek, Fransa devletinin üstün konumunu vurgulamaktadır.

\section{«NousSavıonsQueNousÉtıonsMenacés»(www.lemonde.fr)}

\section{"Tehdit edildiğimizi biliyorduk"}

Alt başlık, yine, Hollande'ın söyleminden alıntıdır. Yaşananlara karşı hazırlıksız olmadıklarını belirtmesi, yine halk üzerinde bir çeşit güven duygusu yaratmak, karşı tarafta ise üstün duruşunu korumayı istemektedir.

"“ Noussommes dans un moment difficile, plusieursattentatsavaientétédéjoués, noussavionsquenousétionsmenacés, car noussommes un pays de liberté », a-t-il continué."

“Le chef de l'Etatvateniruneréunion à l'Elysée à 14 heures, en présence « desministres et responsablesquisontconcernés par la 
protectionquenousdevonsassurer à tousleslieuxoù de mêmesactespourraientê trerenouvelés, par lesmêmesbarbares ». Ilinterviendraensuite à 20 heures à la télévision."(www.lemonde.fr)

"Zor bir zamandayız, birçok saldırı engellenmişti, tehdit edildiğimizi biliyorduk, çünkü biz bir özgürlük ülkesiyiz" şeklinde devam etti.

- Devlet Başkanı, "aynı barbarlar tarafından, aynı girişimlerin tekrarlayabileceği tüm yerlerde bizim sağlamamı gereken korumayla ilgilenen bakanlar ve yetkililerle" saat 14.00 'te Elysée'de bir toplantı yapacak. Sonrasında, saat 20.00 'de televizyona katılacaktır.

Hollande'ın halk üzerinde "güven yaratmayı" ve panik durumunu kontrol altına almayı amaçlayan söylemi devam etmektedir. "Biz" söylemiyle vatandaşlara bir bütünlük çağrısı yapılmaktadır. Bu söylemi habere taşıyan gazete de, kendisini aynı birlik içerisinde konumlandırmıştır. Haberin tamamına bakıldığında, resmi ideoloji söyleminin doğrudan aktarıldığı, bir çeşit "devletin sesi" olduğu görülmektedir. Bu haberde yer alan vurgulara bakılarak, gazetenin ideolojik söyleminin resmi söylemle paralel olduğu söylenebilir.

\subsubsection{Le Figaro}

1826 yılından bu yana yayınlanan Le Figaro gazetesi, muhafazakâr sağ kanada yakın olarak bilinmektedir. 07 Ocak 2015 tarihinde yayınlanan haber metni (www.lefigaro.fr) Türkçeleştirilerek analiz edilmiştir.

"Tirsausiège de Charlie Hebdo : dixmorts, cinqblessésgraves" (www.lefigaro.fr)

- $\quad$ Charlie Hebdo'nun merkezine ateş: on ölü, beş ağır yaralı

Haberin başlığı saldırının sonucuna yönelik bilgi vermektedir. Saldırının kimler tarafından gerçekleştirildiği belirtilmemiştir.

"Dixpersonnesontététuéesmercredimatin dans l'attaquedeslocaux de Charlie Hebdo, indique le parquet de Paris. Cinqblessésgravessontégalement à déplorer. Ils'agit de l'attentat le plusmeurtrier en France depuis 1995." (www.lefigaro.fr)

Paris hâkimler savcılar odası, Çarşamba sabahı Charlie Hebdo ofislerine yapılan saldırıda 10 kişinin öldürüldüğünü bildirdi. Beş ağır yaralı da aynı şekilde üzüntü yarattı. Bu, 1995 yılından beri Fransa'daki en ölümcül saldırı.

Saldırıda ölen ve yaralananların hakkındaki bilgiler doğrudan verilmek yerine, haberin kaynağından aktarımıştır. Geçmişe dönük bilgi de sunularak, saldırının ciddi boyutunun altı çizilmektedir.

"Charlie Hebdo : uneattaque "sansprécédent" contre la presse" ( www.lefigaro.fr)

Charlie Hebdo: basına karşı "eşi benzeri görülmemiş" saldırı

Alt başlıkta da saldırının sorumluları hakkında bir bilgi yoktur. Onun yerine, birinin 
söyleminden alıntılandığı anlaşılan başıkta, yine saldırının "özel” niteliği dile getirilmiştir ve vahametine vurgu yapılmıştır. "Basına karşı" ifadesi, gazetenin bu konudaki hassasiyetini göstermektedir. Basın bu noktada aynı cephede konumlandırılmıştır.

"L'attaquearméecontre le journal Charlie Hebdo, qui a faitaumoinsdouzemortsmercredi à Paris, estuneattaque "sansprécédent" contre la presse en France, a soulignéChristopheDeloire, secrétairegénéral de Reporterssansfrontières (RSF). "Uneattaquebarbare çömme celle-là, c'estuneaffairesansprécédent", a déclaré sur la chaîneiTÉLÉChristopheDeloirequis'estrendu sur place dans le Xlearrondissement." (www.lefigaro.fr)

Sınır Tanımayan Gazeteciler Genel Sekreteri ChristopheDeloire, Paris'te Charlie Hebdo gazetesine Çarşamba günü gerçekleşen ve on iki kişinin ölümüne sebep olan silahlı saldırının Fransa'daki basına karşı düzenlenmiş "benzeri olmayan" bir saldırı olduğunun altını çizdi. XI. Bölgede olay yerine giden ChristopheDeloire ITELE kanalında "Bunun gibi barbarca bir saldırı, benzeri görülmemiş bir olaydır" dedi.

Basın özgürlüğü adına mücadele eden Deloire'ın sözleriyle olayı aktaran haberin bu bölümünde saldırı kınanmaktadır ve saldırının alışılagelmiş saldırılardan çok farklı olduğunun altı çizilmiştir. Benzer açıklamalar birçok kurum ve kuruluştan gelebildiği halde, basın özgürlüğünü savunan uluslararası bir sivil toplum örgütü temsilcisinin sözlerine yer verilmesinin gazetenin duruşuyla ilgili bir tercih olduğu düşünülmektedir.

"C'estdeschosesqu'onvoitmalheureusement dans despayscomme le Pakistan, la Somalie", a-t-il relevé. "In'y a pas d'agressionplusgrandecontre la liberté de la presse et contretoutesleslibertésque de s'attaquer à un journalqui a simplement le tortd'exerc erpleinementsalibertéd'expression", a ajoutéChristopheDeloire." (www.lefigaro.fr)

"Bunlar ne yazıkki Pakistan, Somali gibiülkelerdegördüğümüzşeyler" dedi. Christophe Deloire, "basın özgürlüğünekarşıvetümözgürlüklerekarşı, sadecetama menifadeözgürlüğünükullananbirgazeteyesaldırmaktandahabüyükbirşiddetyoktur” diyeekledi.

Haber Deloire'ın ifadeleriyle devam etmektedir. İlk cümlede, Fransa'da yaşanan olayın, Pakistan ve Somali gibi demokrasinin ve özgürlüklerin gelişmediği, ekonomik anlamda Güney ülkeleri sınıflandırmasında olan iki ülkede yaşanan olaylarla karşılaştııılması, eleştirel bir yaklaşımdır. Fransa gibi tarihten bugüne, dünyanın başlıca güçleri arasında bulunan, Cumhuriyet ve demokrasi anlamında çok ileri konumlandırılan gelişmiş bir ülkede bu türden bir olayın yaşanmış olması eleştirilmektedir. Yaşanan olay Fransa gibi bir devlete yakıştırılamamıştır. Cümlede "Fransa bu duruma mı geldi?" anlamı doğmaktadır. Bir ülkenin, bir devletin bu şekilde eleştiriliyor olması, bu devletin yönetiminin de eleştiriliyor olduğu anlamına gelmektedir. Bu da gazetenin muhalif duruşunu desteklemektedir. Deloire'ın ikinci cümlesinde ise, haberin genelinde olduğu gibi ifade özgürlüğü ve basın özgürlüğüne odaklanılmıştır.

\subsubsection{La Croix}

La Croix, siyasi olarak tamamen sağ veya sol olarak tanımlanmayan, daha çok Kilise'nin ideolojisini benimseyen Katolik bir Fransız gazetesidir. Analizi yapılan haber 
(www.lacroix.com, 2015), olayın gerçekleştiği gün olan 7 Ocak 2015 tarihine aittir.

“"Charlie Hebdo », cibled'attaquesrécurrentes" (www.lacroix.com)

"Charlie Hebdo", yinelenen saldırıların hedefi

Haberin başığı konuya ilişkin hiçbir detay, bilgi içermemektedir. Sadece bir saldırı olduğu söylenmektedir. "Yinelenen" ifadesi ile derginin geçmişine gönderme yapılmıştır.

"La fusilladeayantfait 10 mortsausiège de Charlie Hebdomercredi 7 janvierestd'unegr avitésansprécédent. Mais le journalsatirique a déjàsubiplusieursattaquescesdernières années."(www.lacroix.com)

7 Ocak Çarşamba günü, Charlie Hebdo'nun merkezinde 10 ölüye sebep olan silahlı saldırı, daha önce görülmemiş bir şiddet düzeyindedir. Ama mizah gazetesi son yıllarda zaten pek çok saldırı yaşamıştır.

Haberin sadece bu ilk cümlesinde olaya ilişkin bilgi yer almaktadır. Bu bilgi ise sadece ölü sayısını ve olayın gerçekleştiği günü bildirmektedir. Öte yandan, paragrafın ikinci cümlesi, gazetenin geçmişine gönderme yapmakta, "ama" ve "zaten" ifadeleri ile gazetenin genel anlamda bir hedef olduğunu, dolayısıyla yaşanan durumun çok da şaşırtıcı olmadığını ifade etmektedir. Bu cümle, La Croix gazetesinin bu haberi, Charlie Hebdo'ya saldıranların da birtakım sebepleri olduğu kanaatiyle yazdığını düşündürmektedir.

"IncendıeCrımınel En 2011" (www.lacroix.com)

"2011'de Kundakçılık"

"En novembre 2011, leslocaux de Charlie Hebdoétaientpartiellementdétruits par lesflammes. L'hebdomadairesatiriqueétaitvictimed'unincendiecriminel, en représaillesd'unnuméroconsacré à l'islamradical et rebaptisé « ChariaHebdo », représentant en unecaricature de Mahomet."(www.lacroix.com)

2011 Kasım ayında, Charlie Hebdo ofisleri alevlerle kısmen yıkılmıştı. Muhammed'in bir karikatürünü göstererek, radikal İslam'a ayrılmış/ konu alan ve adı "ChariaHebdo" olarak değiştirilmiş bir sayıya misilleme olarak haftalık mizah gazetesi kundaklama kurbanı olmuştu.

$\mathrm{Bu}$ alt başlıkta yer alan bilgiler gazetenin geçmişinde yaşadığı bir başka saldırı hakkındadır. Mevcut saldırının nedenleri haberde yer almazken, geçmişte yaşanan bu kundaklama olayının nedeninin açıkça İslamiyet'e karşı yapılan karikatür olduğu belirtilmiştir. "Misilleme" sözcüğü kullanımıyla, gazetenin yaptığının da bir saldırı olduğu, bu nedenle kundaklamayı yapanların bu saldırıya yanıt verdiği görüşü aktarılmaktadır. Ancak mizah dergisinin "kurban" olarak nitelendirilmesi, "misilleme" sözcüğü ile kurulan eşitlik durumunu bozmaktadır.

“Attaquelnformatique En 2012”(www.lacroix.com) 


\section{2'de Bilişimsel Saldırı}

"Le 19 septembre 2012 aumatin, le site Internet de Charlie Hebdoétaitvic timed'unpiratageaprèsavoirpublié de nouvellescaricaturesduprophète de l'islam. L'attaqueavaitétécondamnée, maisl'hebdomadaireavaitaussireçu de nombreusescritiques en raison de ses " provocations "."(www.lacroix.com)

İslam peygamberinin yeni karikatürlerini yayınlamasının ardından, 19 Eylül 2012 sabahı, Charlie Hebdo internet sitesi hackkurbanı oldu. Saldırı cezalandırılmıştı, fakat dergi de "provokasyonlarından"dolayı çokça eleştiri almıştı.

Bu alt başlık da bir başka geçmiş olayı anlatmaktadır. Yine sebebin Hz. Muhammed'in karikatürlerinin yayınlanması olduğu belirtilmiştir. Metinde tırnak içerisinde gösterilen "provokasyonlar"a vurgu yapılmıştır. İkinci cümlede, saldırıyı yapanların kim olduğu ve ne şekilde cezalandırıldıklarını belirtmeden, derginin aldığı eleştiri ön plana çıkarılmıştır. Gazetenin kendisi doğrudan bu karikatürlerin provokasyon olduğunu belirtmese de, bu ifadeye yer vererek ve tırnak içerisinde kullanarak, bu şekilde yayın yapmanın "provokasyon" olduğuna söyleminde yer vermektedir. Bu anlatım, yapılanın onaylanmadığı yönünde algı yaratmaktadır.

"La tensionétait telle quedesambassades et desécolesfrançaisesavaientétéfermées dans 20 pays, le vendredi 21 septembre, « par mesure de précaution »."(www.lacroix. com)

- $\quad$ Gerilim öyle bir derecedeydi ki, 20 ülkede bulunan büyükelçilikler ve Fransız okulları, "önlem amaçlı” olarak 21 Eylül Cuma günü kapalı kalmışlardı.

Son cümleyle, geçmişteki saldırının niteliği yansıtılmakta, derginin geçmişte yarattığı provokasyonun boyutlarının ciddiyeti detaylandırımaktadır. Bu bilgiler ile La Croix Gazetesi, derginin yayınlarına sadece ifade özgürlüğü şeklinde bakmamakta, dini hassasiyeti olan kesimlerce tepki toplamasına açıklamalar getirmektedir. Olası saldırıların gerçekleştirilebileceği düşüncesiyle "önlem" alınması, saldıranların, eyleme geçmelerini tetikleyen unsurları görmezden gelmemektedir.

\section{Sonuc}

Bu çalışmada, üçü Türk, üçü Fransız olmak üzere, farklı siyasi ideolojilerden gelen altı gazetenin, 7 Ocak 2015 tarihinde Fransız Mizah dergisi Charlie Hebdo'ya yönelik yapılan silahlı saldırıya ilişkin haber söylemleri incelenmiştir. Çalışmada haber metinlerinin tümü yer almaktayken, Fransızca olan metinler Türkçe'ye çevrilerek analiz edilmiştir. Analizde, gazetelerin sözcük seçimleri, kullandıkları cümle yapılarına bakılmıştır ve bu şekilde ideolojilerini gösteren anlamların nasıl kurulduğu tespit edilmiştir.

Çalışmada, Türkiye'den seçilen gazeteler, aşırı sağ görüşü temsil eden Yeni Akit, merkezde yer alan Hürriyet ve sol görüşü temsil eden BirGün gazeteleridir. Fransa'dan seçilen gazeteler ise merkez solu temsil eden Le Monde, muhafazakâr sağ ideolojiyi benimseyen Le Figaro ve Katolik Kilise 'sinin ideolojini yansıtan La Croix gazeteleridir.

Türkiye'deki gazetelere bakıldığında, haber içeriklerindeki farklılıklar ve sunuş şekilleri 
dikkat çekmektedir. Ele alınması gereken önemli bir unsur, haberin içeriğinde verilen detaylardır. Gazeteler hangi görüşü besleyecek bilgiyi ön plana çıkarmak istiyorlarsa, onun altını çizmekte, karşıt görüşe, yok sayar nitelikte daha az yer vermektedirler veya hiç değinmemektedirler. Örneğin, sağ görüşü temsil eden ve İslami profiliyle bilinen Yeni Akit, dergiye olumsuz göndermeler yapmakta ve pek çok diğer yayın organında olduğu gibi haberi terör saldırısı olarak nitelendirmek yerine, daha yumuşatan bir ifadeyle aktarmaktadır. Bu sırada, saldırıyı düzenleyenlere ilişkin bilgiler saklanmakta, "örgüt" veya "terör" ifadelerine yer verilmemekte ve saldırıda ölenlerin ön plana çıkarılmasının istenmediğini gösterircesine, ölen gazetecilere ilişkin bilgiler de yer almamaktadır. Oysaki sol görüşü temsil eden BirGün gazetesi haberinde çok detaylı ve uzun bir anlatım tercih etmiş ve özellikle ölen gazeteciler ile ilgili oldukça fazla bilgiye yer vermiştir. Onların kariyerlerine ilişkin detaylar haberde yer almaktadır, bu anlatım şekli de gazetenin onlara değer verdiğini göstermektedir ve dolayısıyla durumu vahim bir kayıp olarak anlamlandırmaktadır. Öte yandan merkeze yakın duran Hürriyet Gazetesi, olaya daha dışarıdan bir gözle bakmakta fazla detaydan kaçınmaktadır. Bu durum gazetelerin hangi safta yer aldıklarını gösterir niteliktedir.

Haberi veriş biçimlerinde, bu üç gazetede ideolojiyi yansıtan bir başka önemli ve belirgin nokta da, İslamiyet'e karşı duruşlarıdır. Müslüman iki kişi tarafından gerçekleştirilen bu saldırı, bir kesim tarafından ifade özgürlüğüne saldırı olarak nitelendirilmekteyken bir diğer kesim İslami öğeleri ve Hz. Muhammed'i konu alan karikatürleri dine ve inançlara yönelik bir saygısızılık olarak değerlendirmiştir. Bu aşamada, Yeni Akit Gazetesi haber söyleminde kullandığı ifadelerle İslami kimliğini açıkça belirtmekte ve karşı tarafın yaptıklarını "küstahlık" olarak nitelendirmekteyken, yani biz ve onlar karşıtlı̆̆ını kurarken, BirGün gazetesi de aynı ayrımı karşıt yönden kurmuştur. Müslüman bir ülke olan Türkiye'de yayın yapan Bir Gün gazetesi, peygamber ile ilgili söylemlerinde, İslami inancın öngördüğü saygı duyan bir ifade biçimi kullanmamıştır. Gazetecilere değer verirken, İslam'a ve peygamberine açıkça değersizlik atfetmiştir.

Gazetelerin ideolojileri doğrultusunda, Fransa devletine yakınlıkları da değişmektedir. Örneğin Hürriyet gazetesi Fransız devleti tarafında olduğunu, dergiyle kendisini "biz" olarak nitelendirdiğini söyleminde vurgulamaktayken, bir yandan da Fransa'nın merkez solunda bulunan, çalışmamızda incelediğimiz gazetelerden biri olan Le Monde'a atıfta bulunarak, neredeyse birebir devletin sesi şeklinde yayın yapan Le Monde gazetesinin söylemini benimsediğini göstermiştir.

Değerlendirmemizin başında da belirttiğimiz gibi, her gazetenin önem verdiği ve altını çizdiği konular farklıdır. Yeni Akit karikatürlere gelen tepkilere dikkat çekerken, Hürriyet tıpkı Türkiye'nin uluslararası arenada yansıttığı gibi yapılan saldırıyı olumsuz olarak nitelendirmekte, BirGün ise ifade özgürlüğü vurgusu yaparken, dünya devletlerince ne şekilde kınandığını, hangi boyutlarda ses getirdiğini, dolayısıyla uluslararası anlamda da tasvip edilmeyen bir saldırı olduğunun altını çizmektedir.

Fransız gazetelerine bakıldığında ise, Türkiye'deki duruma benzer bir farklılık haber söylemlerine yansımıştır. Ancak, sağ ve sol ideoloji temsilleri ve siyasi yanlılıkları Fransa'nın dinamiklerine göre değişiklik göstermektedir. Merkez solu temsil eden Le Monde Gazetesi, birebir, tüm haber boyunca Cumhurbaşkanı Hollande'ın söylemine yer vermiştir. Bu durum, gazetenin ideolojisinin resmi devlet ideolojisiyle örtüştügünün bir göstergesidir. Nitekim Hollande da Sosyalist Parti'den gelen bir siyasetçidir. Diğer 
yandan, Le Figaro'ya bakıldığında, sağ görüş ve muhafazakâr duruşun temsilinden öte, daha çok muhalif bir ses yansıtılmaktadır. Olay Fransa'da yaşandığı için, bir Fransız gazetesi olarak Le Figaro'nun yapılan saldırıyı kınaması ve onaylamaması olağandır. Ancak, muhalif duruşu itibariyle, haberinin söylemini ifade özgürlüğüne odaklamıştır. Daha çok konuyu tüm basın adına ele almış olup, saldırının basın özgürlüğünü hedef aldığını belirtmektedir. Oysaki Le Monde gazetesi, haber söyleminde, saldırının Fransa'ya yönelik olduğunu sıklıkla ifade etmiş, basın ve ifade özgürlüğüne aynı çapta yer vermemiştir. Öte yandan, Le Figaro, yaptığı "Pakistan", "Somali" benzetmesiyle devlete yönelik eleştirel tutumunu sürdürmektedir.

Fransa'dan incelenen bir diğer gazete La Croix ise, diğer iki gazeteden farklı olarak, Fransa'da yayınlanıyor olmasına karşın, dini değerlerin altını da çizer nitelikte, derginin "ifade özgürlüğünü" kullanış biçimini çok da haklı bulmamaktadır. Dergiye yönelik yapılan saldırıların gerekçelendirilmesi, geçmişte yapılan saldırıların nedenlerinin detaylandırılması, gazetenin derginin bu yayınlarına eleştirel bakışını sergilemektedir. Haber metninde, dergiye sert bir eleştiri yapılmazken, derginin yayın şeklinin bu tür sonuçlar doğurabileceğini ifade eden anlatım, dini değerler yok sayılarak mizah yapıldığında, "yaptırımlarının" da ağır olacağının altını çizmektedir. $\mathrm{Bu}$ haberle, gazetenin diğer Fransız gazetelerinden ayrıldığı görülmektedir. Burada, Katolik Kilisesi'nin duruşunun desteklenmesi ve dolayısıyla olayın dini bakış açıyla ele alınması söz konusu olmuştur.

\section{Kaynakça}

Althusser, L. 2003. İdeoloji ve Devletin İdeolojik Aygıtları, (Çev.) Alp Tümertekin, İstanbul: İthaki Yayınları.

Aydın, F. B. (2013). Haber Söyleminde Siyasal Etki ve İdeoloji: 2002 ve 2011 Genel Seçimlerinin Karşılaştırmalı Analizi. Konya Selçuk Üniversitesi. Yüksek Lisans Tezi

Chomsky, N.,Herman, Edward S., Peterson,D., Podor, J.( 2004). Medyanın Kamuoyu İmalatı, İstanbul: Chiviyazıları.

Çam, Ş. (2008). Medya Çalışmalarında İdeoloji Epistemolojik ve Metodolojik Sorunlar, De Ki Yayınları.

Devran, Y. (2010). Haber, Söylem, İdeoloji, İstanbul: Başlık.

Durna, T. ve Kubilay, Ç. (2010). Söylem Kuramları ve Eleştirel Söylem Çözümlemeleri, T. Durna (der.) Medyadan Söylemler 1.B. içinde s: 47-81, İstanbul, Libra Kitap.

Hall, S.,Critcher, J., Clarke, J., Jefferson, T., ve Roberts, B. (1978). Policing the Crisis: Mugging, the State and Law and Order, GB: Methuen.

İnal, A. (1996). Haberi Okumak, Temuçin Yayınları, İstanbul.

İnceoğlu, Y. ve Çomak, N. 2009. Metin Çözümlemeleri, İstanbul: Ayrıntı Yayınları.

Kula, N. 2002. Gazetelerde Yer Alan Polise Yönelik Haberlerdeki Söylemsel Boyutlar: Gaffar Okkan Suikastı Örnek Olayı, Polis Bilimleri Dergisi, 4(1-2), 187-203. 
Özer, Ö. (2008). “'deolojik Atmosferin Kapsama Alanı: Bozüyük Olaylarının Ortadoğu ve Ülkede Özgür Gündem Gazetelerinde Sunumu Örneğinde Haber Söyleminde Yapılan İdeolojik Üretime iliş̧kin Yeni Bir Çözümleme", Türkiye,de Sivil İtaatsizlik Toplumsal Hareketler ve Basın (Der: E. Dağtaş). Ankara: Ütopya Yayınevi, s. 377-432.

Özer, Ö. (2011). Haber Söylem İdeoloji, Literatürk Yayınları, Konya.

Poyraz, B. (2002). Haber ve Haber Programlarında İdeoloji ve Gerçeklik, Ütopya Yayınevi, Ankara

Şeker, T. ve Şeker, M. (2011). "Televizyon Haberlerinde Söylem: 29 Mart 2009 Yerel Seçimler Örneği", S.Ü. Türkiyat Araştırmaları Dergisi, Sayı:30 (Güz), Konya, 515-552.

Şen, F. (2013). Sağlık Hakkı ve Medya: "Sağlıkta Dönüşüm Programı"nın Medyada Yansımaları. Galatasaray Üniversitesi Dergi. 155-174.

Umunç, C. (2013). "1915 Ermeni Olaylarına Yönelik "Soykırım” Algısı Yaratmada Kullanılan Görsel Materyallerin Eleştirel Söylem Analizi", 1. Uluslararası Medya Çalışmaları Sempozyumu Bildiriler Kitabı, Antalya, 305-315.

Van Dijk, T.A. (1988). News as Discourse, Lawrence EarlbaumAssociatesPublication, New Jersey.

Van Dijk, T.A. (1988a). News Analysis, Lawrence EarlbaumAssociatesPublication, New Jersey.

Van Dijk, T.A. (1999). "Söylemin Yapıları ve İktidarın Yapıları", Medya İktidar İdeoloji, Mehmet Küçük (der. ve çev.), 2. Baskı, Ark Yayınları, Ankara.

Van Dijk, T. A. (2003). "Söylem ve İdeoloji Çokalanlı Bir Yaklaşım”, Içinde Söylem ve İdeoloji Mitoloji-Din-İdeoloji, Hazırlayanlar Barış Çoban ve Zeynep Özarslan, Çev. Barış Çoban, Zeynep Özarslan, Nurcan Ateş, Su Yayınları: 13-112.

İnternet Kaynakları

“Charlie Hebdo'ya saldırı: Charb, Cabu, Wolinski ve Tignous yaşamını yitirdi”http://www.birgun. net/haber-detay/charlie-hebdo-ya-saldiri-charb-cabu-wolinski-ve-tignous-yasamini-yitirdi-73658. html. Erişim tarihi: 03.06.2015.

"Paris'te Charlie Hebdo dergisine silahlı saldırı"http://www.hurriyet.com.tr/pariste-charlie-hebdodergisine-silahli-saldiri-27911771. Erişim tarihi: 03.06.2015.

"Charlie Hebdo ", cibled'attaquesrécurrentes" http://www.lacroix.com/Culture/Medias/CharlieHebdo-cible-d-attaques-recurrentes-2015-01-07-1263362. Erişim tarihi: 01.06.2015

"Tirsausiège de Charlie Hebdo : dixmorts, cinqblessésgraves"http://www.lefigaro.fr/flashactu/2015/01/07/97001-20150107FILWWW00161-tirs-au-siege-de-charlie-hebdo-dix-mortscinq-blesses-graves.php. Erişim tarihi: 01.06.2015.

"Attaquecontre « Charlie Hebdo » : Hollandeparle d'« attentatterroriste»" http://www.lemonde.fr/ attaque-contre-charlie-hebdo/article/2015/01/07/attaque-contre-charlie-hebdo-hollande-parle-dattentat-terroriste_4550728_4550668.html. Erişim tarihi: 01.06.2015. 
"Paris'te Küstah Mizah Dergisine Saldırı" http://www.yeniakit.com.tr. Erişim tarihi: 03.06.2015 http://atelier.leparisien.fr/sites/Je-Suis-Charlie/les-faits/le-resume-des-faits Erişim tarihi: 01.06.2015 